\title{
COMMENTARIES: THE ENTRENCHMENT OF A BLL OF RIGHTS
}

In these commentaries, $L$. C. Green augments the discussion of specific problems associated with the entrenchment of a bill of rights, such as the meaning we attach to the term "entrenchment", the wording of the proposed Charter, and future amendment. Gil Remillard treats the topic within the broader perspective of the Trudeau Resolution, the nature of Canadian federalism, regionalism and Quebec/Canada duality.

\section{C. GREEN*}

Because I agree so much with many of Professor Schmeiser's remarks, what I have to say will, to a great extent, be more supplementary thereto than commentary thereupon.

I must begin, as did Professor Schmeiser, by expressing my bias. Coming from the national background that I do, and in spite of the number of years that I have been away from England, I do not fundamentally regard a bill of rights as absolutely essential. While living in England, I knew by and large what my rights were even though I might not have been able to find any specific document setting out those rights. The British Bill of Rights to which Professor Schmeiser referred this morning is not a bill of rights in the sense in which Canadians generally understand this term. The Bill of Rights in the United Kingdom was rather concerned with parliamentary rights against the noble, powerful monarch. It is necessary to be careful when considering the meaning of this and other terms in the context of the Canadian situation.

For example, what do we mean by entrenchment? We hear so much about entrenchment and patriation that to some extent we may be losing the fundamentals of the dispute: the problem of the provincial-federal controversy over powers and competencies. The word entrenchment has become a broad emotional term, as emotional as the word patriation. Both of them are being used by politicians and by organs of the media. Neither of these groups has apparently bothered to read the Statute of Westminster, the British North America Act, or the proposals that are now before the House of Commons in Ottawa.

The "Bill of Rights" in the United States is comprised of a series of amendments to the United States Constitution. Those amendments are no more "entrenched" than any other amendment to the United States Constitution. What has been entrenched into the Constitution can also be disentrenched. For example, the eighteenth amendment, introducing Prohibition, constitutionally and legally had as much status as the amendments constituting the Bill of Rights. A later amendment repealed the prohibition amendment. These are elements of an "entrenched" bill of rights that we need to recognize.

When we say that we would like an entrenched bill of rights we are saying that we have certain ideas that we think ought to have the same standing as our constitution. This also indicates that we have changed the nature of the concept of parliamentary supremacy in this country so that a particular act passed at a particular time by a particular House of Commons is seen to be

- LL.B., LL.D., F.R.S.C., University Professor, University of Alberta. 
more sacrosanct than any other piece of legislation passed by a House of Commons at any other time.

Another intriguing point is that this is to be the great Canadian Charter of Rights. The act to amend the Constitution of Canada declares "be it therefore enacted by the Queen's most Excellent Majesty by and with the advice and consent of the Lords Spiritual and Temporal and Commons in this British Parliament assembled". Our great Canadian Act, our Constitution Act, will in fact be a British statute. It further states that:

... the Constitution Act set out in Schedule B to this act is hereby by the British Government enacted for and shall have the force of law in Canada; and shall come into force as provided. No act of the Parliament of the United Kingdom passed after this Act shall extend to Canada as part of its law.

Presumably once this act is passed we can get on with the country's business. However, there may be a need to put the whole matter back before the Canadian House of Commons because of the vagaries of our political system. A fascinating situation may arise if between the adoption of the Canada Act, the Constitution Act of 1981, by the British Parliament, and its reception in Canada, we have a general election and a change of government. The resulting situation offers many possibilities. I have never been convinced that the government of yesterday, having become today's Opposition, is certain that it was right when it formed the government. Nor am I convinced that the desires of an Opposition remain unaltered when it comes to power. We might find that the present Opposition, if it came to power, would change its view as to the value of the bill that it is now opposing.

There are much more serious problems with regard to what is proposed by way of entrenchment. Professor Schmeiser referred to the exception clause. I have been interested in the problem of human rights for a long time, and regard the Charter as being the expression of our desire to give effect, not to the Universal Declaration, but to the Covenants of Human Rights which we have ratified and which are therefore, in law, binding upon us. I notice, however, that we only bother with the Covenant on Political and Cultural Rights and not with the one on Economic and Social Rights. This is rather a strange approach to those who believe in fundamental freedoms. The Charter says, as Professor Schmeiser pointed out, that the exceptions would have to be demonstrably justified in a free and democratic society. This statement raises many questions. Who is to do the demonstrating? To whom is the demonstration to be made? Once the demonstration is made, who shall decide whether the society is free and democratic? Are Zimbabwe and Vietnam free and democratic societies? And our allies, the United States? Or, individually, the states of the Union? It depends on what colour you are, what religion you are, and where you stand at any particular time on any particular issue.

The questions are important because the wording used in the Charter is very close to the wording in international documents. There was a test of this wording before the European Court of Human Rights in a dispute between Ireland and the United Kingdom over the treatment of Irish internees. There the British government was entitled to take such exceptional measures as were necessary in time of emergency to preserve a democratic society. The European Court of Human Rights, in its great wisdom, stated that it was necessary to recognize that the decisions as to whether there was an emergency, as to whether the exceptional measures were required by the exigencies of the situation, and whether there was maintenance of a democratic society, shall be made in the first instance by the British government. 
Other problems arise with relation to the proposed Charter of Human Rights. First, each individual has his or her own views about fundamental rights, and which of those rights should be protected. Second, in some areas everyone has rights, while in other areas only citizens have rights. In the same chapter, one section will relate to citizens, and another will relate to individuals; yet we are talking about human rights without discrimination of any kind: nationality, language, etc.. Third, the Charter guarantees equal rights to all individuals regardless of sex, language, age, religion, colour. Having made that guarantee I have never understood why we say that we also need special rights for women, special rights for the blind or the deaf, special rights for children and so on. The automatic assumption is that they are somehow peculiar types within the definitions of humans or individuals. Why is it assumed that if a particular group is specified there will be more respect for that group than there will be if that group is considered to be a part of the generality? Either the Charter means something or it does not. If it cannot be trusted in general terms, it cannot be trusted in specific terms.

There is a further problem, to which Professor Schmeiser drew attention: the problem of rigidity. If the Charter is embodied in a document that is difficult of amendment, the situation arises where technological development may well outrun the value of the document. There is a recent English decision with relation to this issue which may be of considerable importance. It is the case of Royal College of Nursing v. The Department of Health and Social Security. ${ }^{1}$ This is a very recent case. The House of Lords delivered its final decision about three weeks ago, overruling Lord Denning once again. The case related to the right of abortion under the Abortion Act of 1967. ${ }^{2}$ That Act provided that surgical abortions (which were the only type known in 1967), were to be performed by a registered medical practitioner. However, there have been developments whereby nurses, paramedics, even interns, and possibly third and fourth year medical students could participate in the process. Lord Denning held that since they were not registered medical practitioners, they could not perform abortions according to the new techniques. The House of Lords pointed out that it is necessary to recognize the developments in techniques in surgical process. It is apparent that similar situations could arise in Canada with relation to technological changes in the human rights field.

The difficulty may arise, not only with respect to technological developments, but also with respect to changes in community standards. This can be illustrated by reference to the United States Supreme Court decisions in Plessy v. Ferguson ${ }^{3}$ and Brown v. The Topeka Board of Education, ${ }^{4}$ the famous schools case. In Plessy, the Supreme Court stated: "On the basis of an entrenched Bill of Rights, if separate facilities are equal there is no breach of the Constitution". In the schools case, they said: "If there are separate facilities, whether they are equal or not, there is a breach of the Constitution". They were interpreting the same provisions, the same Bill of Rights, in the

1. Royal College of Nursing of the United Kingdom v. Department of Health and Social Security [1981] 2 W.L.R. 279 (C.A. and H.L.).

2. Abortion Act 1967 (U.K.), 1967 c. 87.

3. Plessy v. Ferguson (1896) 163 U.S. 537.

4. Brown v. Topeka Board of Education (1955) 349 U.S. 294. 
context of a changed community standard.

So many countries which are casting off "the last vestiges of colonialism" have entrenched all sorts of fundamental rights in their new constitutions. One country in particular is Zimbabwe. It is a very interesting question for Canadians to consider, as to whether the white population of Zimbabwe, which had its rights entrenched into the constitution, is very convinced of the value of that entrenchment.

\section{GIL REMILLARD*}

Professor Schmeiser points out the main problems in relation to the entrenchment of human rights. But I think it is important for a better understanding of the implications of the Charter to look at that charter in the general constitutional context of the Trudeau Resolution. The events we are experiencing today with the Trudeau Resolution have no precedent in the history of Canadian federalism. They will no doubt shape its evolution to a great extent. In fact, the constitutional Resolution touches the very essence of our federalism, by asking Parliament to unilaterally patriate the constitution in accordance with the Resolution, including an amendment formula, a charter of fundamental rights and freedoms and the principle of resource sharing.

There are many questions we can ask. First of all, I would like to say that it is difficult to understand why the patriation of the constitution has given rise to so much discussion. In fact, all parties concerned seem to agree that a full revision is called for. It is natural that after more than 113 years' experience, we would want to revise the compromise of 1867 in order to make it conform to our modern needs. Insofar as we agree on the need for constitutional revision there is hardly any need to patriate the constitution. All that has to be done is to let the whole British document die a peaceful death at home in the Westminster Parliament.

It should be understood that the Statute of Westminster, because of our patriation problems, is much more than a simple British law. It is to some extent an international treaty between Canada, which actually was already sovereign prior to 1931, and England, but it is also a Canadian federalprovincial agreement with relation to section 71 . As long as provincial legislatures and the Canadian Parliament agree on the terms of a new constitution, there is no need to go to the English Parliament. The Statute of Westminster is a conventional text, the Canadian implications of which may be left to the discretion of the Canadian parties involved, in other words to the provinces and Ottawa. To me, the patriation of the constitution is, in this sense, a false problem. Only if the unamimity rule were to be changed or if it were decided to carry out only a partial constitutional revision would patriation of the constitution become an issue. The British Parliament could then delay approval of the required law and thus protect the rights of one or several dissenting provinces. 
The Westminster Parliament is not the watchdog of the unanimity rule, but merely the party safeguarding the B.N.A. Act, which has not yet been patriated. The role of the British Parliament in the matter of patriating the constitution is limited in international law according to the Statute of Westminster. However, the manner in which the British Parliament is proceeding clearly shows that it is somewhat uneasy or uncomfortable with the Trudeau Resolution. This stalling tactic, to which the British Parliament seems to want to resort, can be an excellent way for us to reach a compromise among ourselves. It is understandable that some people are exasperated by the problems we are experiencing in carrying out to the satisfaction of all parties concerned a revision of the constitution, a process which is becoming increasingly urgent.

The furor of the conference held last September in Ottawa clearly proves that the constitutional crisis which we are facing is due to the confrontation between two fundamentally different concepts of Canadian federalism. A coup de force such as the Trudeau Resolution is surely not conducive to resolving the constitutional crisis. In fact, the Resolution is merely a first step in the comprehensive revision which is called for. In what climate will the revision process be undertaken after British law has sanctioned unilateral action of this nature?

Federalism is much more than a political system. It is above all a philosophy, a way of behaving and thinking based on the concept of compromise. We must establish this philosophy together mindful of the challenge facing us, namely a troubled world situation and a complex internal specificity. The charter of fundamental rights and freedoms, the amending formula proposals and the principles respecting the sharing of our resources in the Resolution raise doubts about the very nature of the philosophy underlying Canadian federalism.

Where the charter of rights and freedoms is concerned, even if the preamble refers to the broad principle of democracy, the text of the new Canadian constitution must, in the early going, establish a charter of the most fundamental rights applicable to all Canadians. Today it is the duty of a society which calls itself democratic to entrench the fundamental rights which it is planning to guarantee to its citizens. In Canada the act of entrenching fundamental rights has created problems since it raises questions about regionalism and the duality of our federal system. Canada is a vast, sparsely populated country. Therefore it is completely natural for Canada to have various regions, each with its own very specific attitudes and lifestyles. In this sense, the entrenchment of fundamental rights can lead to many problems. Regionalism is a very real aspect of the Canadian federal system. Western Canada, the Maritimes, Ontario, and Quebec constitute four regions, each having very specific spiritual and economic characteristics. It is therefore impossible to deny to the provinces a certain amount of jurisdiction over fundamental rights. This is not in itself reason enough to refuse to entrench this right in the constitution.

It is clear that entrenching fundamental rights limits the sovereignty of Parliament and awards interpretative powers to the courts. In England where parliamentary sovereignty is a quasi-absolute principle, fundamental rights are protected by a tacit extra-constitutional agreement. Important British constitutional documents such as the Bill of Rights, Magna Carta, and the Act of Settlement constitute the source of individual freedoms. In 
view of its sovereign nature, Parliament could entirely amend these texts. However, since the rights granted by these documents have traditionally been guaranteed, it would, to all intents and purposes, be unthinkable for Parliament to amend them. Furthermore, it has become customary for certain practices established by the courts to become true commonwealth principles. The spirit of this British tradition regarding fundamental rights was applied to Canada in the preamble of the B.N.A. Act, which stipulates that we are governed by a constitution similar in principle to that of the United Kingdom. In addition to this common law provision we must include the Canadian Parliament's Bill of Rights and the special legislation of certain provinces and the other sections of the B.N.A. Act in relation to human rights.

Canada is a country where fundamental rights are comprehensive and highly respected. As Alexander Hamilton wrote in The Federalist when he drafted the United States Constitution: "Supreme protection of all freedoms is the breath of freedom spread across the entire nation. Legal means are useless if they are not upheld by public sentiment." Public sentiment in Canada is especially developed and has been supported and even emphasized by the interpretations of the courts, which drafted a true charter of fundamental freedoms well before the Canadian Parliament devised the Bill of Rights in 1960. However, it must be understood that Canada is not a homogeneous country like Britain. Furthermore, our parliamentary traditions are not exactly the same as those of the United Kingdom. For example, Parliament was able to pass legislation such as the War Measures Act and apply it in the manner in which it did in Quebec in 1970.

The entrenchment of fundamental rights in the constitution also raises the problem of Canada duality. In the opinion of those who feel that duality constitutes the union of French-speaking and English-speaking nations in Canada, linguistic rights should constitute a fundamental freedom and as such should be entrenched in the constitution. This position corresponds to the traditional concept of two founding nations as developed by the Royal Commission on Bilingualism and Biculturalism, 1963. The proponents of this thesis logically conclude that every Canadian should be able to speak his or her language everywhere in Canada. There is no need to express the enormous problem involved in applying this policy. It has been said that:

The hopes held by Francophones, especially those in Quebec, whereby they would be able to live in French anywhere in the country have been broken and will undoubtably continue to be broken in future. As for Anglophones, they still do not understand why they are morally obligated, not necessarily to learn French, but to provide services in French where there are no Francophones to benefit from this service or none who want to do so.

The Task Force on Canadian Unity (the Pepin-Robarts Task Force), reached a very similar conclusion. After noting that the rate of linguistic assimilation of French speaking minorities was quite high and appeared to be accelerating in all provinces, the Task Force reached the following conclusion: ${ }^{1}$

In our opinion the protection of linguistic rights at the provincial level can be treated, at this time, in either one of two ways: extending the constitutional guarantees of section 133 to every or to some provinces or removing these guarantees, inviting the provinces to legislate safeguards for their minorities, taking into account the diversity of the local situations with the hope that a concensus

1. Task Force on Canadian Unity: A Future Together, Government of Canada (Ottawa, 1979) 52. 
between the provinces might form on a common denominator which eventually could be included within the constitution of the country. After due consideration we now think that the second option would be wiser and more likely to be successful in the long run, involve less confrontation, and be more in agreement with the spirit of the federal system.

In reaching this conclusion the Task Force acknowledged the national phenomenon which exists in Quebec and the reality of Quebec/Canada duality. In this sense it is therefore impossible to insert in the constitution language rights without, in the process, making Quebec even more French in nature. However, it will be necessary to entrench language rights in the constitution in relation to the constitution and administration of the federal government.

We therefore conclude that it will be necessary to entrench fundamental rights in the new constitution. However, this charter of fundamental rights should not include language rights except at the level of federal government and its administration. This will be a first step and if necessary could be followed by an amendment to the constitution. 